\title{
The Obstacles Preventing Postgraduate Students from Benefiting from Scholarship Programs at Helwan University
}

\author{
Neveen saber Abd El-hakim (PhD) \\ Casework Department \\ Basem Youssief Mohamed El-Moazen \\ (PhD) \\ Community Organization Department \\ Faculty of Social Work, Helwan University
}


The Egyptian Journal of Social Work (EJSW) http://ejsw.journals.ekb.eg

Print ISSN: 2356-9204 Online ISSN: 2356-9212 Vol 6, Issue 1, June 2018

\begin{abstract}
:
The study aimed to identify the obstacles faced by postgraduate students who have the potential to benefit from scholarship programs at Helwan university, and aims to proposals for overcoming obstacles, from the viewpoint of researchers, for potential students to benefit from scholarship programs at Helwan university. the study community is a group of 50 students taking postgraduate studies at the faculty of social work at Helwan university. Social Survey methodology was used, and a measure was used to identify the most significant obstacles that are faced by students without the benefit of scholarship programs. the data were processed through the computer using the SPSS (V.19) statistical packages for social sciences. the study found several results, the most important of which was the lack of data and information being available about the terms and conditions of scholarship programs. other obstacles included: difficulty of making use of scholarships following late advertisement; non-application of clear criteria for nomination and deliberate development conditions that do not apply to many researchers but disrupt them; the weakness of the provider donor and health problems effecting access to the scholarship; lack of a foreign cultural center providing services in preparation of scholarship students; lack of access to computer training courses in scientific research; poor knowledge of university terms for scholarships; difficulty in understanding some of the courses; difficulty in attending lectures in donor countries; difficulty of language communication with donor state supervision; and poor access to academic guidance.
\end{abstract}

Key words: Scholarships - Postgraduate students - obstacles.

Introduction:

Education has become a strategic resource for modern societies because its reach extends throughout specialized scientific cadres. if education is the basis of progress, and the primary responsibility for shaping the future, and higher education is the cornerstone of progress, so the continuous development of the system of higher education is essential. education is crucial to the lives of societies and nations as the only way to bring about civilized development and strong economies, culturally and socially. one of the most important indicators of human development, on the other hand, is represented by investment in human capital. the civilizational development of societies is measured not only by the volume of physical investment but also by the achievement of scientific and cognitive production and 


\begin{tabular}{||lcr|}
\hline $\begin{array}{l}\text { The Egyptian Journal of Social Work (EJSW) } \\
\text { Print ISSN: 2356-9204 }\end{array}$ & Online ISSN: 2356-9212 & Vol 6, Issue 1, June 2018 \\
\hline
\end{tabular}

the evolution of education in human capacity-building and the development of skills and capabilities. (Mincer, 1958; Schultz, 1961 \& Becker, 1962).

Today, higher education has become the first choice for countries that wish to gain more advanced knowledge and functions, and thus gain more influence in the information age. neither ordinary capital nor even traditionally trained human capital is enough to guarantee better future. (Sidawi, 2000, p. 234).

Universities are considered the most important institutions of higher education, and since ancient times they have been at the forefront of society; they are the center of knowledge and innovation, and a forum for pioneers of innovation and development. postgraduate studies represent a stage of education that has a great impact on the refinement and composition of individuals, preparing them for life and making their way in the future, so many modern educational systems show great interest in this stage. research and study at this stage form just a small part of this interest.

The topic of scholarship for students abroad has generally received great Arab and global attention. for many reasons it comes at the forefront of debate due to the high cost, which is most often borne by the state, as well as the growing hope that scholarship will enriches the overall development of their country. studies have been conducted in Arab and European countries, including the study (Mohsen, M.: 2015), the study recommended the adoption of a strategic plan for the development of international students at university, and the need to solve the problems they face, and the intensification of scientific studies and research into the subject of international students.

A study (Aldaya, W., 2015) and a study (Fayed, F., 2014) and a study (Zakaria, M.: 2011) found that there were differences in the evaluation of the performance of the Office, but that scholarship students can participate in many of the opportunities offered by the university and can operate on campus in the same way as the rest of the students, and found a lot of academic problems which facing students; the difficulty of choosing the required specialization, the problems of English language learning, and high tuition fees.

A study (EL Samih, A., 2004) and a study (Randall, Yamamoto, Nakamoto, Arakaki, 1998) and (Shabeeb, S.6 1997) and (H., Paul A: 1995) and (Al yahya, M. A., 1995) the administrative and educational difficulties facing university scholarship students including 75\% experiencing delayed reward and poor telephone service in housing, 
\begin{tabular}{llc}
\hline $\begin{array}{l}\text { The Egyptian Journal of Social Work (EJSW) } \\
\text { Print ISSN: } 2356-9204\end{array}$ & Online ISSN: 2356-9212 & Vol //ejsw. journals.ekb.eg \\
\hline
\end{tabular}

$50 \%$ having average free internet and poor transport service, the high price of university restaurants and books. a small 25\% experiencing other problems, including: delayed formal actions and negative attitudes from some fellow student housemates, and personnel and social problems that determine the forms and levels of tension, and the English language was the most difficult adjustment area.

Therefore, many states are trying to meet their development needs by sending a selection of their own to pursue postgraduate studies at home or abroad in certain disciplines, and for multi-level scientific degrees as needed: $\mathrm{BA}-\mathrm{Ma}-\mathrm{PhD}$ to prepare their children professionally and scientifically to keep up with the challenges in the changing age

Through previous studies and research related to overseas scholarship students, clearly, they suffer from many of the pressures and problems that hinder their social, personnel, cultural and academic consensus. additionally, the studies show their inability to forge successful social relationships with others due to their lack of social interaction skills for different societal and cultural backgrounds.

They cannot adopt and easily correspond with them, which often generates their feelings of distress and depression. by looking at previous studies, the emphasis is on meeting scholarship students although the terms of their nomenclature differ-for different problems weather they are social, cultural, educational, economic, health, personnel or moral, family or security. however, these studies have varied in the detection of these problems, as some studies have theoretically discussed them as a study of the (AL-Yehya ,1995) and study of the (EL-Sameh, 2004).

Most studies have agreed with focus on academic and administrative problems facing scholarship students, accept for the study of (H. Paul A (1995) and the study of Randall, Yamamoto, Nakamoto, Arakaki, (1998) which focused on economic and psychological problems. the focus of most studies on educational, social, administrative, economic and personnel problems are fundamental as the results of studies vary.

This study has benefited from foregoing studies in emphasizing the importance of addressing the constraints faced by scholarship students

Given the focus of the general practice of social work on dealing with different systems to help solve its problems and achieve its objectives, it was taken from the perspective of the ecological systems 
The Egyptian Journal of Social Work (EJSW) http://ejsw.journals.ekb.eg

Print ISSN: 2356-9204 Online ISSN: 2356-9212 Vol 6, Issue 1, June 2018

and one of the most important theoretical frameworks that direct the professional touch (Al-Nouhi, A., 2007, p. 80).

Because the graduate students are influenced by the environment surrounding the social systems and interact with them and the resulting problems, the result of this interaction will use the researcher's ecological perspective in the interpretation of the results of the study and analysis

The importance of this study: The study therefore came as an attempt to uncover the obstacles faced by postgraduate students' access to scholarship programs at Helwan university and identify the most important proposals by the researchers to overcome those constraints. and provide decision makers at the university with a set of recommendations; proposals that would help to overcome the administrative, social and cultural constraints facing postgraduate students with the potential to benefit from scholarships.

Objectives of the study: the study aims to identify the obstacles to benefitting from scholarship programs at Helwan university that postgraduate students face.

Study Questions: the first main question of the study was: What are the obstacles hindering postgraduate students in benefitting from the scholarship programs at Helwan university? A number of secondary questions emerged from this hypothesis:

1- What are the obstacles related to publicity and media that prevent students from benefiting from scholarship programs?2- What are the obstacles that relate to the objectivity of the nomination preventing students from benefiting from scholarship programs?3- What are the obstacles related to the adequacy of funding preventing students from benefiting from scholarship programs?4- What are the obstacles related to the professional preparation of the students that prevent them benefitting from scholarship programs?5- What obstacles related to research and academic aspects prevent students from benefiting from scholarship programs?6- What are the obstacles related to social and cultural aspects that prevent students from benefiting from scholarship programs?

The second main question of the study: What are the proposals to overcome the obstacles that hinder students of social work in benefitting from scholarships in postgraduate programs at the university of Helwan? 
The Egyptian Journal of Social Work (EJSW) http://ejsw.journals.ekb.eg

Print ISSN: 2356-9204 Online ISSN: 2356-9212 Vol 6, Issue 1, June 2018

\section{The theoretical part of the study:}

\section{First. Concepts of the study: This study includes basic concepts.}

A -The concept of scholarships: Essawi defined a scholarship and the opportunity offered by the University to students for free study in one or more levels of education; undergraduate, postgraduate level. (Essawi, A., 2002: pp. 11-12).

\section{B - The concept of obstacles procedure:}

1. Obstacles related to the adequacy of funding: the inability of postgraduate students to obtain free scholarships, with difficulties in funding, and lack of financial assistance or loans, especially with the high cost of education, health and housing.

2. Obstacles related to professional preparation: the weakness of the language of communication and incompatibility with other cultures and different religions, and the lack of familiarity with the values, customs and traditions of other societies. Inability to follow up everything that is new in the society joined, and the lack of information and knowledge about the culture of donor countries.

3.Obstacles related to information and publicity: the lack of knowledge of and information available to postgraduate students on the nature of scholarships provided, and funding or reductions available.

4. Obstacles related to the objectivity of the nomination: the weakness in the application of clear criteria for the nomination and deliberately set conditions that do not apply to many researchers but are limited to certain people.

5. Obstacles related to research and academic aspects: the difficulty of courses and lack of competence. the problems of academic councils, registration and lack of compatibility with supervision colleagues, administrators and academic supervisors, and lack of compatibility with teaching methods. the lack of availability of the required references in a difficult educational climate.

6. Obstacles related to social and cultural aspects: the lack of personnel and social adjustment, the inability to deal with different social attitudes, and the difficulty of moving away from the family and the absence of the family atmosphere. 


\begin{tabular}{|lcc|}
\hline $\begin{array}{l}\text { The Egyptian Journal of Social Work (EJSW) } \\
\text { Print ISSN: 2356-9204 }\end{array}$ & Onttine ISSN://ejsw.journals.ekb.eg \\
\hline
\end{tabular}

Second: the obstacles faced by scholarship students: there are many obstacles that can be faced by scholarship students, which are illustrated by the study (Abdulrahman, M. H., 2010, pp. 428-427)

- Failure to pass the language requirement.

- Most researchers finish their messages and do not want to start again.

- Sometimes students need to start studying a new language they do not know.

- Some family circumstances such as caring for parents.

- Some faculty members see that the scholarship will not generate any material income, such as the financial return it will receive within the country.

- Lack of English language education for both the university and postgraduate levels.

- Lack of proficiency of the researcher in the English language enabling him to deal with the internet and read foreign books. There are some universities that require a level of proficiency in English at the local level and this is not enough to prepare a good researcher.

The results of the study (Hynie, M., 2011) showed the importance of students acquiring research and professional skills as well as a good understanding of theoretical information. Doris (1991) recommended the importance of organizing scientific meetings among scholarship students and academic supervisors to identify their problems, and that older students have to help new students to overcome these obstacles.

Economic and financial constraints: many scholarship programs faced many problems that prevented them from achieving their objectives. the most important of these was the problem of providing financial resources, which caused many of the problems that effected the achievement of the objectives for which they were established, including in the academic field, scientific research, community service, hardware, buildings and equipment.

Where education is facing through the scholarships a lot of constraints that limit the efficiency and impair the quality of its outputs and the possibility of development, the most prominent of these restrictions, and the biggest impact on the educational process, is the limited sources of funding and the low efficiency of allocation to the components of the educational process. This hinders the possibility of developing education and improving the quality of its outputs. (Beltagy, M. M., 2009, p. 6). economic constraints are the inability of 
\begin{tabular}{|lcr|}
\hline $\begin{array}{l}\text { The Egyptian Journal of Social Work (EJSW) } \\
\text { Print ISSN: 2356-9204 }\end{array}$ & Onttine ISSN://ejsw.journals.ekb.eg \\
\cline { 1 - 1 }
\end{tabular}

the student to obtain an expensive educational service (Sarhan, M. M., 2003, p. 246), such as higher living expenses if accompanied with tightness of hand (Rashid, A., 1988, p. 65). and Irregularity in the disbursement of the monthly rewards (Alsaghir, S. M., 1995, p. 24). and difficulty of mobility and transportation (Rashid, A., 1988, p. 67).

This is what many studies as research have shown; there are financial problems or problems related to funding research, and difficulty in obtaining resources or obtaining assistance for scholarship students. the study of (Mark, S., 2010 \& Joon, Y., 2010) (Dorsi, 1991) emphasized the need to provide opportunities for university recruitment for scholarship students, scholarships and soft loans for education. Mark Sherry (2010) demonstrated the need to improve financial assistance for scholarships through university community initiatives, which was confirmed by (Joon Yung, 2010).

Academic obstacles: the lack of funding has negatively affected the university performance to obtain scholarships, which led to "the decline of academic and educational qualities and competencies, and the reason for the migration of high competencies to the centers or universities which give the most expensive salaries" (Rahma, Antoine. 2000: p. 9). Scientific research is considered one function of the university, and to promote the teaching process, any university must encourage scientific research because "there is no good education unless there is advanced scientific research, and purpose to solve the problems of society, scientific and sophisticated technology "(Ghuneima, M.: 2002: p. 39).

As the results of many studies have shown, there are academic, research and study problems for scholarship students. The results of the study (Dong, p., 2002) emphasized the need to prepare students before applying for scholarships to benefit from the experience of foreign universities.

Social and cultural obstacles: one factor that may lead to social and cultural problems are the transfer from one country to another due to temporary immigration such as study, or permanent immigration for other reasons. these immigrants, including scholarship students, are in urgent need of knowledge of some of the characteristics of the new society. this knowledge is often drawn from other individuals, such as peers, who have a personnel experiences that vary from other peoples' personnel experiences. how much they need a particular type of service to overcome difficulties may lead them to adopt some hostile ideas (EL-Khankawi, I. M., 1996, pp. 88-89). 


\begin{tabular}{|lcr|}
\hline $\begin{array}{l}\text { The Egyptian Journal of Social Work (EJSW) } \\
\text { Print ISSN: 2356-9204 }\end{array}$ & Onttine ISSN://ejsw.journals.ekb.eg \\
\cline { 1 - 1 }
\end{tabular}

As many studies have pointed out, there are social and cultural problems for scholarship students, which are characterized by personnel and social incompatibility, psychological problems such as feelings of alienation, loneliness and isolation, and cultural problems such as the lack of compatibility with new cultures (Doris, 1991) (Joon, 2010), (Mohamed, 1991) and (Mark et.al, 2011).

Methodology: This study belongs to the descriptive study and seeks to determine the obstacles which faced the postgraduate students, this study used Social survey using the sample.

Fields of study:

The human sample: The College of social work has 150 students for postgraduate studies, and the sample consisted of (50) students at the postgraduate stage of college have been selected based on:

- Attend these students regularly.

- The fact that the students are in the study stage either master or doctorate.

- These students wish to receive a scholarship.

Spatial Field: This study was applied in the faculty of social work at Helwan University.

Time domain: the study ran from 10/8/2017 until 1/12/2017.

Study limitation: the researchers encountered several difficulties in conducting their studies, but they were overcome as follow:

A- the difficulty of the theoretical framework for the subject of scholarships, because its information is not available in the social service. the researchers were able to overcome this difficulty by looking at the information in all publications, scientific periodicals and modern technological means such as the Internet and others. B - the difficulty of previous studies: to the knowledge of the researchers did not conduct a previous study in social work on the subject of scholarships and has been able to overcome this through the development of several axes of previous studies dealing with the dimensions of the study and try to obtain previous studies at the Arab and local levels.

C. the difficulty of selecting the sample of the study: the researchers were able to select a number of students in all sections of the faculty of social work, and this helped the researchers to implement the program.

Study Tools: the study tools were defined in a measure to identify the obstacles that prevent the benefit of scholarship programs, which includes a range of dimensions. 


\begin{tabular}{||lcc|}
\hline $\begin{array}{l}\text { The Egyptian Journal of Social Work (EJSW) } \\
\text { Print ISSN: 2356-9204 }\end{array}$ & Online ISSN: 2356-9212 & Vol 6, Issue 1, Junc 2018 \\
\hline
\end{tabular}

A- The Scale Dimensions: the dimensions of the scale was determined in light of the theoretical framework of the study and in the light of previous studies.

B- Composing the Statements of the Scale: In light of the definition of each dimension, and after reviewing some of the previous studies and questionnaires that deal with scholarship, 100 phrases were formulated covering all the axes that were selected, and with (17) words for each axis of axes capable of a single interpretation.

C- (Face Validity): the dimensions of the scale was presented to a group of experts in social work to judge their validity, suitability of the field in which they were put, $(80 \%)$ and more to determine the validity of the paragraph. In light of this, the indicator excluded 17 paragraphs and thus the number of paragraphs of the questionnaire was (83).

The tool was approved: this tool was presented to 10 faculty members in the faculty of social work at Helwan university. the agreement was not less than $(80 \%)$. the form was completed.

Global Truthfulness "the Truthfulness of Internal consistency":

Table (1) Internal consistency among the variables of the questionnaire form for postgraduate students and the degree of the form as a whole (N 25)

\begin{tabular}{|l|l|l|l|}
\hline No & Dimensions & $\begin{array}{l}\text { Pearson } \\
\text { Correlation }\end{array}$ & $\begin{array}{l}\text { Significance } \\
\text { tailed) }\end{array}$ \\
\hline 1 & $\begin{array}{l}\text { Obstacles related to information } \\
\text { and publicity. }\end{array}$ & 0.721 & $* *$ \\
\hline 2 & $\begin{array}{l}\text { Obstacles related to the objectivity } \\
\text { of nomination. }\end{array}$ & 0.953 & $* *$ \\
\hline 3 & $\begin{array}{l}\text { Obstacles on the adequacy of } \\
\text { funding. }\end{array}$ & 0.939 & $* *$ \\
\hline 4 & $\begin{array}{l}\text { Obstacles related to professional } \\
\text { preparation in the interior. }\end{array}$ & 0.962 & $* *$ \\
\hline 5 & $\begin{array}{l}\text { Obstacles related to research and } \\
\text { academic aspects. }\end{array}$ & 0.971 & $* *$ \\
\hline 6 & $\begin{array}{l}\text { Obstacles related to social and } \\
\text { cultural aspects. }\end{array}$ & 0.934 & $*$ Significant \\
\hline
\end{tabular}

** Significant at $(0.01) \quad *$ Significant at $(0.05)$

It is clear from the previous table that the dimensions of the tool function are at a significant level $(0.01)$ for each dimension and shows the level of confidence in the tool and reliability of results.

Reliability of the tool: the questionnaire was applied to a random sample of 10 postgraduate students to ascertain the clarity of the questionnaire, as well as the time taken to answer the questionnaire. In 


\begin{tabular}{llc}
\hline $\begin{array}{l}\text { The Egyptian Journal of Social Work (EJSW) } \\
\text { Print ISSN: } 2356-9204\end{array}$ & Online ISSN: 2356-9212 & Vol //ejsw. journals.ekb.eg \\
\hline
\end{tabular}

responding to the paragraphs of the questionnaire the postgraduate students took time ranging from (15 minutes to 20 minutes) and an average of (17.5 minutes). the reliability of the tool was calculated by using the Alpha Cronbach reliability coefficient for the estimated stability values of the questionnaire of postgraduate students benefiting from scholarship programs at Helwan university for a sample of 25 postgraduate students. the results of the study were as shown in the next Table:

Table (2) Shows the reliability of results using the Alpha Cronbach coefficient for the questionnaire of postgraduate students benefiting from scholarships programs $(\mathrm{N}=25)$

\begin{tabular}{|c||l||c||}
\hline $\mathbf{N}$ & Variable & $\begin{array}{l}\text { Coefficient } \\
\text { (alpha Cronbach) }\end{array}$ \\
\hline \hline 1 & $\begin{array}{l}\text { Reliability of the questionnaire of } \\
\text { postgraduate students who benefit from } \\
\text { scholarship programs as a whole. }\end{array}$ & 0.91 \\
\hline
\end{tabular}

Study Results:

Table (3) Disporting the subjects according to their qualitative variables $(\mathrm{n} / 50)$

\begin{tabular}{|c|c|c|c|}
\hline No & Qualitative variables & Frequencies & $\begin{array}{l}\text { Percentage } \\
\%\end{array}$ \\
\hline 1 & $\begin{array}{l}\text { - Gender: } \\
\text { a- male. } \\
\text { B- female. } \\
\end{array}$ & $\begin{array}{l}9 \\
41 \\
\end{array}$ & $\begin{array}{l}18 \\
82 \\
\end{array}$ \\
\hline 2 & $\begin{array}{l}\text { Age: } \\
\text { a- less } 25 . \\
\text { B- } 25- \\
\text { C- more } 35 . \\
\end{array}$ & $\begin{array}{l}20 \\
30 \\
0\end{array}$ & $\begin{array}{l}40 \\
60 \\
0\end{array}$ \\
\hline 3 & $\begin{array}{l}\text { Degree: } \\
\text { a- master. } \\
\text { B- PhD. }\end{array}$ & $\begin{array}{l}20 \\
30 \\
\end{array}$ & $\begin{array}{l}40 \\
60 \\
\end{array}$ \\
\hline$\overline{4}$ & $\begin{array}{l}\text { Do you know any information about } \\
\text { scholarship programs at Helwan university? } \\
\text { a- yes. } \\
\text { B-no. }\end{array}$ & $\begin{array}{l}12 \\
38\end{array}$ & $\begin{array}{l}24 \\
76\end{array}$ \\
\hline$\overline{55}$ & $\begin{array}{l}\text { Have you received training courses related to } \\
\text { scholarships? } \\
\text { a- yes. } \\
\text { B-no. }\end{array}$ & $\begin{array}{l}7 \\
43\end{array}$ & $\begin{array}{l}14 \\
86\end{array}$ \\
\hline
\end{tabular}

The results of the above table show that: the sample of the study was mostly female $(82 \%)$, the percentage of males was $(18 \%)$, and the post-graduate students were more than $(25 \%),(60 \%)$ of them were in 


\begin{tabular}{|lcc|}
\hline $\begin{array}{l}\text { The Egyptian Journal of Social Work (EJSW) } \\
\text { Print ISSN: 2356-9204 }\end{array}$ & Onttine ISSN: $2356-9212$ & Vol 6, Issue 1, June 2018 \\
\hline
\end{tabular}

the doctoral stage and $40 \%$ of them were in the master's degree. the number of students who did not know anything about the scholarship programs in Helwan was $(76 \%)$ as opposed to $(24 \%)$, and a lot of postgraduate students $(86 \%)$ did not receive any training related to scholarships, with only $(14 \%)$ who are dealing with scholarship programs with the University.

(A) Results related to constraints related to information and publicity:

Table (4) Shows obstacles related to information and publicity as determined by postgraduate students ( $\mathrm{n} / 50)$

\begin{tabular}{|c|c|c|c|c|c|c|c|}
\hline \multirow[b]{2}{*}{$\mathrm{N}$} & \multirow[b]{2}{*}{ Phrases } & \multicolumn{3}{|l|}{ Answers } & \multirow{2}{*}{$\begin{array}{l}\text { Total of } \\
\text { weights }\end{array}$} & \multirow[b]{2}{*}{ Mean } & \multirow[b]{2}{*}{ Rank } \\
\hline & & Always & $\begin{array}{l}\text { Some } \\
\text { times }\end{array}$ & No & & & \\
\hline 1 & $\begin{array}{l}\text { Difficulty benefiting from } \\
\text { scholarships } \\
\text { advertised late. }\end{array}$ & 28 & 22 & 0 & 128 & 2.56 & 2 \\
\hline 2 & $\begin{array}{l}\text { It is advertised on a } \\
\text { university-specific website. }\end{array}$ & 11 & 35 & 4 & 107 & 2.14 & 6 \\
\hline$\beta$ & $\begin{array}{l}\text { Delay in their arrival to the } \\
\text { Scientific Departments. }\end{array}$ & 21 & 22 & 7 & 114 & 2.28 & 5 \\
\hline 4 & $\begin{array}{l}\text { Limited advertising of } \\
\text { these scholarships. }\end{array}$ & 26 & 24 & 0 & 126 & 2.52 & 3 \\
\hline 5 & $\begin{array}{l}\text { Intentionally hide any data } \\
\text { about the outstanding } \\
\text { scholarships offered by the } \\
\text { university. }\end{array}$ & 9 & 24 & 17 & 92 & 1.84 & 8 \\
\hline 6 & $\begin{array}{l}\text { Lack of data } \\
\text { information related to grant } \\
\text { program terms } \\
\text { conditions. }\end{array}$ & 38 & 8 & 4 & 134 & 2.68 & 1 \\
\hline 7 & $\begin{array}{l}\text { Lack of cooperation by } \\
\text { officials in clarifying any } \\
\text { data associated with these } \\
\text { scholarships. }\end{array}$ & 3 & 27 & 20 & 83 & 1.66 & 9 \\
\hline 8 & $\begin{array}{l}\text { Lack of sufficient } \\
\text { information on how to } \\
\text { communicate with donors. }\end{array}$ & 24 & 22 & 4 & 120 & 2.40 & 4 \\
\hline 9 & $\begin{array}{lr}\text { Shortages in } & \text { advertising } \\
\text { programs } & \text { about } \\
\text { scholarships. } & \\
\end{array}$ & 13 & 22 & 15 & 98 & 1.96 & 7 \\
\hline & ariable as a whole & & & & 11.33 & 2.22 & mean \\
\hline
\end{tabular}

The above table shows that: the most important obstacles related to advertising and publicity, as defined by postgraduate students, came first from the lack of data and information related to the terms and 


\begin{tabular}{|lcc|}
\hline $\begin{array}{l}\text { The Egyptian Journal of Social Work (EJSW) } \\
\text { Print ISSN: 2356-9204 }\end{array}$ & Onttp://eiswe ISSN: 2356-9212 & Vol 6, Issurnals.ekb.e 1, June 2018 \\
\hline
\end{tabular}

conditions of scholarship programs with an average of (2.68). the second place was the difficulty of benefiting from scholarships that are announced late, (2.56). Thirdly, the announcement of these scholarships was limited to an average of (2.52). the penultimate obstacle was that which concealed any data about outstanding scholarships offered by the university with an average of (1.84), and finally the clarification of any salary data about these scholarships are given by an average of (1.66).

B- Obstacles related to the objectivity of the nomination.

Table (5) Obstacles related to objectivity of candidacy as determined by postgraduate students $(\mathrm{n} / 50)$

\begin{tabular}{|c|c|c|c|c|c|c|c|}
\hline \multirow[b]{2}{*}{ N } & \multirow[b]{2}{*}{ Phrases } & \multicolumn{3}{|c|}{ Answers } & \multirow{2}{*}{$\begin{array}{l}\text { Total of } \\
\text { weights }\end{array}$} & \multirow{2}{*}{ Mean } & \multirow[b]{2}{*}{ Rank } \\
\hline & & Always & $\begin{array}{l}\text { Some } \\
\text { times } \\
\end{array}$ & No & & & \\
\hline & $\begin{array}{l}\text { Everyone has the right to } \\
\text { self-nomination without } \\
\text { exception. }\end{array}$ & 15 & 32 & 3 & 112 & 2.24 & 7 \\
\hline 2 & $\begin{array}{l}\text { Not applying clear criteria } \\
\text { for nomination. }\end{array}$ & 38 & 9 & 3 & 135 & 2.70 & 1 \\
\hline$\beta$ & $\begin{array}{l}\text { Intentionally concealing the } \\
\text { free scholarships by the } \\
\text { sponsors. }\end{array}$ & 4 & 40 & 6 & 98 & 1.96 & 9 \\
\hline 4 & $\begin{array}{l}\text { Deliberately setting } \\
\text { conditions that do not apply } \\
\text { to many researchers. }\end{array}$ & 27 & 17 & 6 & 121 & 2.42 & 2 \\
\hline 5 & $\begin{array}{l}\text { Difficult conditions have } \\
\text { been established to obtain } \\
\text { these scholarships. }\end{array}$ & 29 & 10 & 11 & 118 & 2.36 & 5 \\
\hline 6 & $\begin{array}{l}\text { Difficulty communicating } \\
\text { with those responsible for } \\
\text { these scholarships. }\end{array}$ & 19 & 31 & 0 & 119 & 2.38 & 4 \\
\hline 7 & $\begin{array}{l}\text { The intransigence of some } \\
\text { heads of scientific } \\
\text { departments in the } \\
\text { nomination of researchers. }\end{array}$ & 19 & 27 & 4 & 115 & 2.30 & 6 \\
\hline 8 & $\begin{array}{l}\text { College administration } \\
\text { intransigence in nominating } \\
\text { researchers. }\end{array}$ & 24 & 6 & 20 & 104 & 2.08 & 8 \\
\hline 9 & $\begin{array}{l}\text { Limiting } \\
\text { programs to some people } \\
\text { only. }\end{array}$ & 15 & 26 & 9 & 106 & 2.12 & 7 \\
\hline 10 & $\begin{array}{l}\text { Deliberately disabling the } \\
\text { researchers, which miss } \\
\text { them the opportunity to } \\
\text { benefit from these } \\
\text { scholarships. }\end{array}$ & 27 & 17 & 6 & 121 & 2.42 & $\begin{array}{l}2 \\
\text { Duplicat } \\
\text { e }\end{array}$ \\
\hline & Iriable as a whole & & & & 114.9 & 2,29 & mean \\
\hline
\end{tabular}




\begin{tabular}{||lcc|}
\hline $\begin{array}{l}\text { The Egyptian Journal of Social Work (EJSW) } \\
\text { Print ISSN: 2356-9204 }\end{array}$ & Online ISSN: 2356-9212 & Vol 6, Issue 1, June 2018 \\
\hline
\end{tabular}

The above table shows that: the most important obstacles related to the objectivity of the candidacy as defined by the postgraduate students, came first by failing to apply the clear criteria for nomination with an average of (2.70). the second place was deliberately setting conditions that do not apply to many researchers with an average of (2.42). In joint second place, the researchers were prevented from benefiting from these scholarships by an average of (2.42). in the last penultimate position, the scholarship programs were limited to some people, with an average of (2.12), and finally, intentionally concealing the free scholarships by the sponsors with an average of (1.96).

C. Obstacles related to the adequacy of funding.

Table (6) Obstacles related to the adequacy of funding as determined by postgraduate students $(\mathrm{n} / 50)$

\begin{tabular}{|c|c|c|c|c|c|c|c|}
\hline \multirow[b]{2}{*}{$\mathbf{N}$} & \multirow[b]{2}{*}{ Phrases } & \multicolumn{3}{|c|}{ Answers } & \multirow{2}{*}{ potal } & \multirow[b]{2}{*}{ Mean } & \multirow[b]{2}{*}{ Rank } \\
\hline & & $\begin{array}{l}\text { Alw } \\
\text { ays }\end{array}$ & $\begin{array}{l}\text { Some } \\
\text { imes }\end{array}$ & No & & & \\
\hline 1 & $\begin{array}{l}\text { Lack of financial assistance provided } \\
\text { to researchers by the university. }\end{array}$ & 19 & 31 & 0 & 119 & 2.38 & 5 \\
\hline 2 & $\begin{array}{l}\text { Lack of government financial } \\
\text { support to beneficiaries of these } \\
\text { scholarships. }\end{array}$ & 9 & 35 & 6 & 103 & 2.06 & 9 \\
\hline 3 & "Difficulty obtaining soft loans. & 20 & 30 & 0 & 117 & 2.39 & 4 \\
\hline 4 & Difficulty getting free scholarships. & 9 & 21 & 20 & 89 & 1.78 & 10 \\
\hline 5 & $\begin{array}{l}\text { Rise in housing prices of the donor } \\
\text { state. }\end{array}$ & 29 & 18 & 3 & 126 & 2.52 & 3 \\
\hline 6 & $\begin{array}{l}\text { Increased expenditure of internal } \\
\text { movements of donor countries. }\end{array}$ & 15 & 35 & 0 & 115 & 2.30 & 6 \\
\hline 7 & Problems related to rations. & 20 & 21 & 9 & 111 & 2.22 & 8 \\
\hline 8 & $\begin{array}{l}\text { Lack of advisory assistance to } \\
\text { students. }\end{array}$ & 21 & 18 & 11 & 110 & 2.20 & 7 \\
\hline 9 & $\begin{array}{l}\text { Health problems affecting the } \\
\text { scholarship. }\end{array}$ & 28 & 17 & 5 & 123 & 2.46 & 2 \\
\hline 1 & $\begin{array}{l}\text { Weak double material contribution } \\
\text { from the donor. }\end{array}$ & 35 & 10 & 5 & 130 & 2.60 & 1 \\
\hline \multicolumn{2}{|r|}{ Variable as a whole } & & & & $\begin{array}{l}114 \\
3 \\
\end{array}$ & 2.28 & $\begin{array}{l}\text { mea } \\
\mathbf{n}\end{array}$ \\
\hline
\end{tabular}

The above table shows that: the most important obstacles related to the adequacy of funding as defined by the postgraduate students were, in first place, twice the financial compensation provided by the donor with an average of (2.60), the second place was the health problems affecting the scholarship (2.46), Third place was the increase in the 


\begin{tabular}{|lcc|}
\hline $\begin{array}{l}\text { The Egyptian Journal of Social Work (EJSW) } \\
\text { Print ISSN: 2356-9204 }\end{array}$ & Onttp://eiswe ISSN: 2356-9212 & Vol 6, Issurnals.ekb.e 1, June 2018 \\
\hline
\end{tabular}

housing prices of the donor country with an average of (2.52). in the penultimate position was the lack of financial support provided to the beneficiaries of these scholarships with an average of (2.06), and lastly, the difficulty of obtaining free scholarships with an average of (1.78).

\section{D - Obstacles related to professional preparation within.}

Table (7) Obstacles related to vocational preparation in the interior as determined by postgraduate $(\mathrm{n} / 50)$

\begin{tabular}{|c|c|c|c|c|c|c|c|}
\hline \multirow[b]{2}{*}{ N } & \multirow[b]{2}{*}{ Phrases } & \multicolumn{3}{|c|}{ Answers } & \multirow{2}{*}{$\begin{array}{ll}\text { Total of } \\
\text { veights }\end{array}$} & \multirow[b]{2}{*}{ Mean } & \multirow[b]{2}{*}{ Rank } \\
\hline & & Always & $\begin{array}{l}\text { ome } \\
\text { imes }\end{array}$ & No & & & \\
\hline & $\begin{array}{l}\text { Difficulty acquiring English } \\
\text { language skills. }\end{array}$ & 9 & 30 & 11 & 98 & 1.96 & 10 \\
\hline 2 & $\begin{array}{l}\text { Lack of information on these } \\
\text { scholarships. }\end{array}$ & 10 & 31 & 9 & 101 & 2.02 & 8 \\
\hline & $\begin{array}{l}\text { Lack of a foreign cultural center } \\
\text { that provides services that } \\
\text { contribute to the preparation of } \\
\text { scholarship students. }\end{array}$ & 38 & 12 & 0 & 138 & 2.76 & 1 \\
\hline 4 & $\begin{array}{l}\text { Difficulty communicating with } \\
\text { foreign students to practice } \\
\text { language. }\end{array}$ & 9 & 37 & 4 & 105 & 2.10 & 7 \\
\hline 5 & $\begin{array}{l}\text { Lack of knowledge of how to } \\
\text { communicate with foreign } \\
\text { universities. }\end{array}$ & 6 & 37 & 7 & 99 & 1.98 & 9 \\
\hline 5 & $\begin{array}{l}\text { Weak knowledge of university } \\
\text { conditions for scholarships. }\end{array}$ & 37 & 8 & 5 & 132 & 2.64 & 3 \\
\hline 7 & $\begin{array}{l}\text { Weak knowledge of ways to } \\
\text { communicate with professors, } \\
\text { supervisors and academic } \\
\text { guides. }\end{array}$ & 15 & 29 & 6 & 109 & 2.18 & 6 \\
\hline 8 & $\begin{array}{l}\text { The weakness of the scientific } \\
\text { frameworks provided about the } \\
\text { expected subject of the message. }\end{array}$ & 27 & 22 & 1 & 126 & 2.52 & 4 \\
\hline 9 & $\begin{array}{l}\text { Weak announcement of the } \\
\text { terms of design of foreign } \\
\text { research. }\end{array}$ & 12 & 6 & 32 & 80 & 1.60 & 12 \\
\hline 10 & $\begin{array}{l}\text { Lack of computer training } \\
\text { courses in scientific research. }\end{array}$ & 37 & 13 & 0 & 137 & 2.74 & 2 \\
\hline 11 & $\begin{array}{l}\text { Lack of joint activities that can } \\
\text { help integrate with foreign } \\
\text { students such as student } \\
\text { exchange. }\end{array}$ & 33 & 14 & 3 & 89 & 1.78 & 11 \\
\hline 12 & $\begin{array}{l}\text { Lack of ability to plan time to } \\
\text { end the scientific message. }\end{array}$ & 10 & 40 & 0 & 110 & 2.20 & 5 \\
\hline$\overline{\mathrm{V}}$ & Iriable as a whole & & & & 110.3 & 2.20 & mea \\
\hline
\end{tabular}




\section{The Egyptian Journal of Social Work (EJSW) http://ejsw.journals.ekb.eg \\ Print ISSN: 2356-9204 Online ISSN: 2356-9212 Vol 6, Issue 1, June 2018}

The above table shows that: the most important obstacles related to the professional preparation within, as defined by postgraduate students, came first in the absence of a foreign cultural center that provides services that contribute to the preparation of scholarship students with without an average of (2.76). Second was lack of computer training at (2.74), the third place was the weakness of knowledge of the conditions of the universities to obtain scholarships with an average of (2.64). in the penultimate status, there were no joint activities that could help to integrate with foreign students such as student exchange, with an average arithmetic (1.78), and in the final position was the conditions for the design of foreign research was weak by an average of (1.60).

E. Obstacles related to research and academic aspects.

Table (8) Obstacles related to academic and research aspects as determined by postgraduate students $(\mathrm{n} / 50)$

\begin{tabular}{|c|c|c|c|c|c|c|c|}
\hline & \multirow[b]{2}{*}{ Phrases } & \multicolumn{3}{|l|}{ Answers } & \multirow[b]{2}{*}{ Total of } & \multirow[b]{2}{*}{ Mean } & \multirow[b]{2}{*}{ Rank } \\
\hline $\mathrm{N}$ & & Always & $\begin{array}{l}\text { Some } \\
\text { imes }\end{array}$ & No & & & \\
\hline & $\begin{array}{l}\text { The difficulty of linguistic } \\
\text { communication with the } \\
\text { supervision of the donor state. }\end{array}$ & 32 & 18 & 0 & 132 & 2.64 & 3 \\
\hline 2 & $\begin{array}{l}\text { Difficulty with supervisors to } \\
\text { choose a topic. }\end{array}$ & 11 & 38 & 1 & 110 & 2.20 & 6 \\
\hline 3 & $\begin{array}{l}\text { Lack of clarity of areas to be } \\
\text { specialized. }\end{array}$ & 28 & 17 & 5 & 123 & 2.46 & 5 \\
\hline 4 & $\begin{array}{l}\text { Lack of educational and research } \\
\text { skills. }\end{array}$ & 19 & 2 & 29 & 90 & 1.80 & 9 \\
\hline 5 & $\begin{array}{l}\text { Difficulty understanding } \\
\text { courses. }\end{array}$ & 42 & 6 & 2 & 140 & 2.80 & 1 \\
\hline 6 & $\begin{array}{l}\text { Incompatibility with the teaching } \\
\text { method followed. }\end{array}$ & 6 & 44 & 0 & 106 & 2.12 & 7 \\
\hline 7 & $\begin{array}{l}\text { The difference in the educational } \\
\text { climate in the donor country. }\end{array}$ & 13 & 28 & 9 & 104 & 2.08 & 8 \\
\hline 8 & $\begin{array}{l}\text { Difficulty attending lectures in } \\
\text { donor countries. }\end{array}$ & 39 & 11 & 0 & 139 & 2.78 & 2 \\
\hline 9 & $\begin{array}{l}\begin{array}{l}\text { Weak access to academic } \\
\text { guidance. }\end{array} \\
\end{array}$ & 1 & 35 & 14 & 87 & 1.74 & 10 \\
\hline 10 & $\begin{array}{l}\text { Some courses available do not fit } \\
\text { the exact specialty. }\end{array}$ & 33 & 15 & 2 & 131 & 2.62 & 4 \\
\hline 1 & $\begin{array}{l}\text { Difficulty dealing with academic } \\
\text { advisors. }\end{array}$ & 2 & 21 & 27 & 75 & 1.50 & 11 \\
\hline & Iriable as a whole & & & & 112.45 & 2.24 & mean \\
\hline
\end{tabular}




\begin{tabular}{|lcc|}
\hline $\begin{array}{l}\text { The Egyptian Journal of Social Work (EJSW) } \\
\text { Print ISSN: 2356-9204 }\end{array}$ & Onttp://eiswe ISSN: 2356-9212 & Vol 6, Issurnals.ekb.e 1, June 2018 \\
\hline
\end{tabular}

The above table shows that: the most important obstacles related to the academic and research aspects as defined by the postgraduate students were the difficulty of understanding some of the academic courses with an average of (2.80). Second place was the difficulty of attending lectures in donor countries with an average of (2.78), and the third place was the difficulty of linguistic communication with the supervision of the donor country with an average of (2.64). in the penultimate position was the weakness of the use of academic guidance with an average of (1.74). the last position was the difficulty of dealing with the academic advisors at (1.50).

F - Obstacles related to social and cultural aspects.

Table (9) Obstacles related to social and cultural aspects as determined by postgraduate students ( $\mathrm{n} / 50$ )

\begin{tabular}{|c|c|c|c|c|c|c|c|}
\hline \multirow[b]{2}{*}{$N$} & \multirow[b]{2}{*}{ Phrases } & \multicolumn{3}{|c|}{ Answers } & \multirow{2}{*}{$\begin{array}{l}\text { Total of } \\
\text { weights }\end{array}$} & \multirow[b]{2}{*}{ Mean } & \multirow[b]{2}{*}{ Rank } \\
\hline & & Always & Some & No & & & \\
\hline 1 & $\begin{array}{l}\text { Difficulty in identifying the } \\
\text { customs and traditions of } \\
\text { the host community. }\end{array}$ & 36 & 13 & 1 & 135 & 2.70 & $\beta$ \\
\hline 2 & $\begin{array}{l}\text { False information about the } \\
\text { social life of donor } \\
\text { countries. }\end{array}$ & 10 & 36 & 4 & 106 & 2.12 & 7 \\
\hline 3 & $\begin{array}{l}\text { Difficulty dealing with the } \\
\text { culture of the host country. }\end{array}$ & 11 & 34 & 5 & 106 & 2.12 & $\begin{array}{l}7 \\
\text { Duplicate }\end{array}$ \\
\hline 4 & $\begin{array}{l}\text { Difficulty of language } \\
\text { communication with the } \\
\text { host country. }\end{array}$ & 47 & 3 & 5 & 147 & 2.94 & \\
\hline 5 & $\begin{array}{l}\text { Weak programs that satisfy } \\
\text { the cultural needs of the } \\
\text { host community. }\end{array}$ & 2 & 44 & 4 & 98 & 1.96 & 11 \\
\hline 6 & $\begin{array}{l}\text { Difficulty adapting to the } \\
\text { customs and traditions of } \\
\text { the host society. }\end{array}$ & 34 & 10 & 6 & 128 & 2.56 & $p$ \\
\hline 7 & $\begin{array}{l}\text { Difficulty making friends } \\
\text { with others in the host } \\
\text { country. }\end{array}$ & 18 & 2 & 30 & 88 & 1.76 & 13 \\
\hline 8 & $\begin{array}{l}\text { The loss of communication } \\
\text { with my family prevents } \\
\text { me from traveling. }\end{array}$ & 32 & 14 & 4 & 128 & 2.56 & 5 \\
\hline 9 & $\begin{array}{l}\text { The strong affiliation of my } \\
\text { family prevents me from } \\
\text { just thinking about the }\end{array}$ & 6 & 43 & 1 & 105 & 2.10 & 9 \\
\hline
\end{tabular}




\begin{tabular}{||lrr||}
\hline The Egyptian Journal of Social Work (EJSW) & http://eisw.journals.ekb.eg \\
Print ISSN: 2356-9204 & Online ISSN: 2356-9212 & Vol 6, Issue 1, June 2018 \\
\hline
\end{tabular}

\begin{tabular}{|c|c|c|c|c|c|c|c|}
\hline \multirow[b]{2}{*}{ N } & \multirow[b]{2}{*}{ Phrases } & \multicolumn{3}{|l|}{ Answers } & \multirow{2}{*}{$\begin{array}{l}\text { Total of } \\
\text { weights }\end{array}$} & \multirow[b]{2}{*}{ Mean } & \multirow[b]{2}{*}{ Rank } \\
\hline & & Always & $\begin{array}{l}\text { Some } \\
\text { imes }\end{array}$ & No & & & \\
\hline & scholarship. & & & & & & \\
\hline 10 & $\begin{array}{l}\text { My family rejects the idea } \\
\text { of traveling. }\end{array}$ & 9 & $\sqrt{45}$ & 8 & 95 & 1.90 & 12 \\
\hline 11 & $\begin{array}{l}\text { I miss social skills to } \\
\text { connect with strangers. }\end{array}$ & 3 & 11 & 1 & 137 & 2.74 & $b$ \\
\hline 12 & $\begin{array}{l}\text { I am unable to deal with the } \\
\text { stressful situations that will } \\
\text { confront me in the host } \\
\text { community. }\end{array}$ & 6 & 39 & 5 & 101 & 2.02 & 10 \\
\hline 13 & $\begin{array}{l}\text { My ability to rolve } \\
\text { problems in the host } \\
\text { community is weak. }\end{array}$ & $\overline{37}$ & 7 & 5 & 131 & 2.62 & 4 \\
\hline \multicolumn{2}{|c|}{ Variable as a whole } & & & & 115.7 & 2.31 & Mear \\
\hline
\end{tabular}

The previous table shows that: the most important obstacles related to the social and cultural aspects as defined by the postgraduate students were the difficulty of communicating with the host country by an average of (2.94).the second place was the lack of social skills to communicate with strangers with an average of (2.74), and the third place was the difficulty of identifying the customs and traditions of the host society with an average of (2.70).in the penultimate center, my family rejected the idea of traveling with an average of (1.90). Finally, it was difficult to make friends with others in the host country.

Table (10) the order of obstacles facing postgraduate students as determined by the student themselves $(\mathrm{n} / 50)$

\begin{tabular}{|l|l|l||l|l||}
\hline $\mathrm{N}$ & Obstacles & mean & S. D & Rank \\
\hline 1 & Obstacles related to information and publicity. & 2.22 & 1.873 & 6 \\
\hline 2 & Obstacles related to the objectivity of nomination. & 2.29 & 2.343 & 4 \\
\hline 3 & Obstacles on the adequacy of funding. & 2.28 & 1.761 & 5 \\
\hline \hline & Obstacles related to professional preparation in the & 2.20 & 2.418 & 2 \\
\hline & interior. & & & 2 \\
\hline 5 & Obstacles related to research and academic aspects. & 2.24 & 1.724 & 3 \\
\hline 5 & Obstacles related to social and cultural aspects. & 2.31 & 2.597 & 1 \\
\hline Obstacles as a whole & 2.25 & 1.76 & mean \\
\hline
\end{tabular}

The above table shows that: the order of obstacles for postgraduate students were, in the first place, obstacles related to social and cultural aspects, with an average of (2.31) and a standard deviation (2.59), and in second place, obstacles related to professional preparation in the interior, with an average of (2.20) and a standard deviation of (2.41).

\section{3}




\begin{tabular}{|lcr|}
\hline $\begin{array}{l}\text { The Egyptian Journal of Social Work (EJSW) } \\
\text { Print ISSN: 2356-9204 }\end{array}$ & Onttine ISSN://ejsw.journals.ekb.eg \\
\cline { 1 - 1 }
\end{tabular}

obstacles related to research and academic aspects, with an average of 2.24 and a standard deviation of (1.72) came in fourth place, with obstacles related to the objectivity of nomination, (2.29), standard deviation (2.34), and fifth place, obstacles on the adequacy of funding, with an average of (2.28) and a standard deviation of (1.76), and in sixth and last place related to information and publicity, with an average of (2.22) and a standard deviation of (1.87).

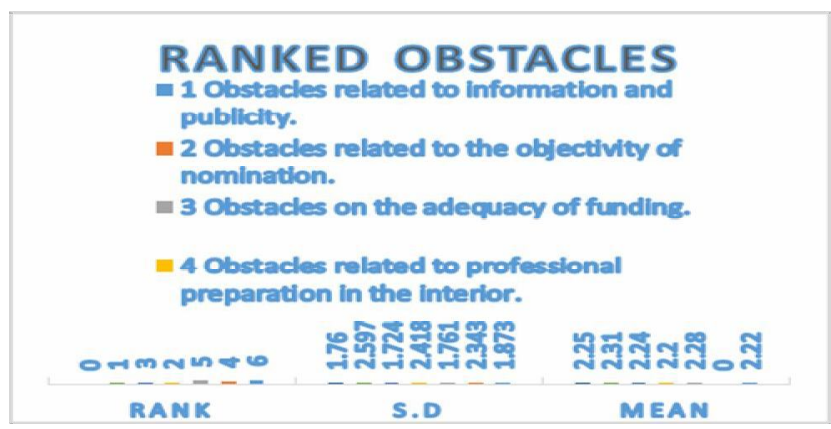

Figure (1) The order of obstacles facing postgraduate students as determined by the students themselves

Seventh: Proposals to overcome the obstacles that face postgraduate students in benefiting from scholarship programs.

Table (11) Proposals to overcome the obstacles identified by postgraduate students themselves.

It is clear from the results of the previous table that: the most important proposals of postgraduate students to benefit from the scholarship programs at Helwan university were as follow: the joint first place was to scholarship students the skill of innovative thinking a postgraduate student with skills in aligning with new cultures, with an average of (2.72). the third place was the training on the skills of language expression in everyday life with an average of (2.7). the fourth place was to provide cultural consultations related to the scholarship before traveling, with an average of (2.52). Fifth was to provide sufficient information about individual and group councils for the scholarship students with an average of (2.48). In the second to last position, the specialists provided support and guidance with an average of (1.68). the last position was to provide skills to deal with the stressful situations expected to be met with (1.36)

Discussion: It is clear from the results of the study that there are a number of obstacles that prevent postgraduate students benefitting from the scholarship programs at Helwan university. the first of these obstacles were related to advertising and represented in the lack of 


\begin{tabular}{||lcc|}
\hline $\begin{array}{l}\text { The Egyptian Journal of Social Work (EJSW) } \\
\text { Print ISSN: } 2356-9204\end{array}$ & Onttp://eisw. journals.ekb.eg \\
&
\end{tabular}

data and information related to the terms and conditions of scholarship programs and the difficulty of benefiting from the scholarships. This is in line with the results of (Khurshid, Hala, 2013), which showed that the university does not provide information to researchers, which helps them to benefit from local and international scholarships and assistance in support of scientific research. the weakness of the announcement of the scholarship processes lead to the difficulty of students in benefitting from those scholarships.

The obstacles related to the objectivity of the nomination is represented in the failure to apply the clear criteria for the nomination and deliberately set conditions that do not apply to many researchers and deliberately disable the researchers, which miss them the opportunity to benefit from these scholarships and also limited the programs of scholarships to some people without others and this is consistent with the results of the study (Jant, 2006), which showed that if the selection of students who are not financially capable is accepted, we will face challenges and underdevelopment for students who have not been prepared to study and become more in need of help and support. if there is a lack of objectivity and clarity in the selection of students, we will encounter many problems. Students from scholarships will be lost. As for the constraints related to the adequacy of funding, the weakness of the financial compensation provided by the donor, the health problems affecting the grant, the high prices of the donor country's house, and the lack of government financial support to the beneficiaries are consistent with the results of the study (Mark Sherry, 2011) which stressed the need to improve the financial aid to scholarship students through the initiatives of the university community, and the study (John, 1995) which stressed the importance of increasing the amounts of funding scholarships so that student do not have to borrow and improving the provision of financial advice. the study by (Farid Ali, 2014) and Mukhtar (Zakaria, 2011) and Salah (El-Lozi, 2008), which emphasized funding problems, the difficulty of resources and assistance to scholarship students, and a fund for scholarship students to borrow from in emergencies.

The obstacles related to the professional preparation of students at home were the lack of a foreign cultural center that provides services that contribute to the preparation of scholarship students, lack of computer training courses in scientific research, poor knowledge of university conditions for scholarships, and the lack of joint activities that can help students to integrate (Dong Ph Young, 2002), which 
\begin{tabular}{|lcr|}
\hline $\begin{array}{l}\text { The Egyptian Journal of Social Work (EJSW) } \\
\text { Print ISSN: 2356-9204 }\end{array}$ & Onttine ISSN://ejsw.journals.ekb.eg \\
\cline { 1 - 1 }
\end{tabular}

stressed the need to prepare students before applying for scholarships, and also agrees to the study (Michaela 2011), which confirmed the need to prepare scholarship students for research and professional skills. This is confirmed by the study of (Joon yung, 2010) and (Joel N dog ,1989), which showed that there were problems with scholarship students due to problems in registration for study, academic guidance and academic supervision.

Concerning the obstacles related to the academic and research aspects, it was difficult to understand some of the courses, the difficulty of attending lectures in donor countries, the difficulty of communication with the supervision of the donor state, and the weakness of the use of academic guidance. This is in line with the results of the study of (Mukhtar Zakaria). The results of the (Julie ,2007) study showed that there is a relationship among the efficiency of the student language and the success of the scholarship programs (Mark Sherry, 2011) and (Joon Yung ,2010). As well as the study of (Fareed Ali, 2014) which showed the presence of academic problems and research in school students.

In addition, the obstacles related to the social and cultural aspects of the difficulty of communication with the host country include; lacking the social skills to communicate with strangers, the difficulty of identifying the customs and traditions of the host society, and the family's rejection of the idea of travel. This is consistent with the results of several studies, (Joel, 2010) and (Joel, 1987), which emphasized the existence of social and cultural problems for scholarship students, including personnel and social incompatibility, psychological problems such as feelings of alienation, loneliness, isolation and cultural problems such as incompatibility with new cultures this is in line with what is also recommended by the study (Dorsi, 1991), which explained the need to provide cultural advice to scholarship students.

The ecological perspective is one of the most appropriate theoretical approaches to the interpretation of these problems in widen the obstacles that confront the postgraduate studies and impede their benefit from the scholarship programs, which refers to the comprehensive and comprehensive view of the problems. this perspective added advantages in the form and essence of the practice including allowing the social worker to deal with a large amount of information Which is obtained from a variety of sources that enable it to factors that may affect the benefit of graduate students from the 


\begin{tabular}{||lcc|}
\hline $\begin{array}{l}\text { The Egyptian Journal of Social Work (EJSW) } \\
\text { Print ISSN: } 2356-9204\end{array}$ & Onttp://eisw. journals.ekb.eg \\
&
\end{tabular}

scholarship programs, which are due to several social systems, and also focuses this perspective on the interactions that occur within this the role of the social environment and the surrounding systems in the occurrence of these problems and the obstacles that hinder their benefit from the programs which are the administrative, financial, research, scientific preparation, etc. These are the following: 1.The postgraduate student format: and the abilities that hinder his ability to benefit from these Programs such as lack of professional preparation and qualification for travel inside and the lack of linguistic preparation, lack of information and experience that enables him to benefit from these programs, with low income, which does not allow him to save to provide the necessary expenses for travel, and the lack of facilities to enable him to get As well as the fear of losing to colleagues and the job and delayed graduation, as well as feelings associated with homesickness and fear of failure and not adopt to the place traveling to it. 2. The College's format in its various scientific departments: It may not provide students with qualifying programs that encourage them to travel and benefit from the scholarship programs, as well as the lack of objectivity in selecting students with a high level of scientific competence and experience in these programs as well as the complexity of the procedures which make it difficult for students to benefit from these grants, with the failure to announce these grants, and may require him to develop a research plan does not help the college in it. 3. University format: The student may face obstacles hindering the bureaucracy of the university to complicate travel procedures, which increases the frustration of the student, and that most of the universities do not nominate the student in the same specialization with the donor group because of the lack of specialization required, forcing him to join the specialization available in the donor community and not provide the necessary funding and palaces in advertising and information on these grants. 4. The management of grant: lack of communication among them and the donor countries, and lack of support for the student beneficiary of the grants, which makes him fear and concern for the loss of communications, and not simplify his tasks and overcome the difficulties he faces. 
The Egyptian Journal of Social Work (EJSW) http://ejsw.journals.ekb.eg

Print ISSN: 2356-9204 Online ISSN: 2356-9212 Vol 6, Issue 1, June 2018

\section{References:}

Abdulrahman, M. H. M. (2010). Scientific research in the Arab World Reality and Hope, research published in the Third Arab Scientific Conference, Arab Universities: Challenges and Prospects - Arab Organization for Administrative Development - Egypt.

Academic, G. C. (2012). Obstacles to Teaching External Scholarships Students, Deanship of Admissions and Registration, Riyadh: Imam Muhammad Bin Saud Islamic University, Saudi Arabia.

Al-Rantisi, M. S. \& Al-Daya, W. (2015). Evaluating the Scholarships Managed by the British Council in Palestine, On the Leadership Capacity Building of the Alumni, Gaza: Palestine.

Al-Ashqar, A. M. (2003). Psychological stress among international students, unpublished Master thesis: National Information Center, Sana'a, Yemen.

Al-Lozi, S. H. (2008). Evaluation of the Office of the Welfare of Foreign Students at the University of Jordan, Muhata for research and Humanities Studies, Jordan: vol. 23.

Al-Nouhi, A. (2007). General Practice in Social Work, "Process of Problem Solving within an Ecological Framework".

Al-Saghir, S. M. (1995). Social Adjustment of International Students an Analytical Study Applied to Foreign Students at King Saud University, Riyadh, faculty of Arts, King Saud University: Riyadh.

Al-Yahya, M. A. (1995). a study of the system of scholarships for Muslim students in the universities of Saudi Arabia, faculty of Education, Egypt: Ain Shams University.

Biltaji, M. M. (2009). Financing Higher Education in Egypt: Proposed Problems and Alternatives, research Paper, Department of Economics, faculty of Economics and Political Science, Cairo University, Egypt: Giza.

El-Khankawi, I. M. (1996). Adult Education and Problems of the Age Studies and Issues, Hail: Dar Al-Andalus for Publishing and Distribution.

EL-Mohsen, M. A., \& Saudi, M. A. (2015). expatriate students of scholarships in Qassim University: manifestations and ways to confront it, research published magazine of Arabic and Human Sciences. 
The Egyptian Journal of Social Work (EJSW) http://ejsw.journals.ekb.eg

Print ISSN: 2356-9204 Online ISSN: 2356-9212 Vol 6, Issue 1, June 2018

EL-Samih, A. M. (2004). Educational and Administrative Difficulties for Scholarship Students, Field Study on Scholarship Students at Imam Muhammad Bin Saud Islamic University, Riyadh: faculty of Social Sciences.

Essawi, A. (2002). Development of Arab University Education, Egypt: Alexandria.

Fayed, F. A. M. (2014). Effectiveness of the general practice in social work in alleviating the stress of life among scholarship students, research published in the social work magazine, Egypt: e. a. o. s. W.

Ghanema, M. (2002). Financing of Education and Contemporary Arab Scientific research New Methods, I 2, Cairo: the Egyptian Lebanese House.

H, Paul A. (1995). problems perceived by in Tensional Students Attending Southern Illinois University at Carbondale, Dissertation abstracts International: vol.56- 7a.

Hynie, M. J. \& Krista. J. M. (2011). student internship bridge research to real world problems, emerald, wagon lane: Howard house, bingley.

Joon -J. (2010). a study of international student's adjustment problems and ameliorating programs at southwestern Baptist theological seminary, $\mathrm{PhD}$, southwestern: Baptist theological seminary.

Khurshid T. M. (2013). Obstacles to Scientific research in Social Work, published in the 16th Scientific Conference, faculty of Social Work, Egypt: Helwan university.

Mincer, J. (1958). "Investment in Human Capital and Personnel Income Distribution." Journal of Political Economy, 66.

Parro, Jon G, (1987). the quality of student financial aid and persistence in college: an analysis of scholarship recipient from the Boston plan for Excellence in the public school, Harvard university.

Rahma, Antoine (2000). the adequacy of the funding of higher education in the Arab countries, their conditions and ways of improving them, the scientific conference accompanying the 33rd session of the Council of the Union of Arab Universities, Beirut, 17-19 April.

Randall, M; N. \& H; Yamamoto \& H; Arkaki. (1998). Assessment of Psychosocial Stressors and Maladjustment among Foreign 
The Egyptian Journal of Social Work (EJSW) http://ejsw.journals.ekb.eg

Print ISSN: 2356-9204 Online ISSN: 2356-9212 Vol 6, Issue 1, June 2018

Student of the University of the Ryukyus: Psychiatry Clinic Neurosci, Vol,52. No.3,

Rashid, Ali (1988). university and teaching university, Jeddah: Dar Al Shorouk.

Sarhan, M. M. (2003). in the Societies of Education. Beirut: House of Arab Renaissance.

Schultz, T. (1961). "Investment in Human Capital." American Economic Review.

Shabeeb- S. Shabeeb, (1997). Saudi and Arabian Gulf students' adjustment problems in Eastern Washington: Gonzaga University.

Sherry, m. \& Thomas, p. \& Chui, w. H. (2010). international students, a vulnerable student population, the international journal of higher education and educational planning,

Sidawi, Ahmed (2000). Trends and Reforms in Higher Education, research published in the Arab Journal of Education, Arab Organization for Education, Science and Culture, Tunisia: December.

Sobeih, L. Z. (2005). The reality of financing Palestinian university education and its problems, published in the first scientific conference "Investment and finance in Palestine between the horizons of development and contemporary challenges, Palestine.

Trong, D. p. (2002). successes, challenges and difficulties experienced by American students while on Fulbright scholarships in china and Vietnam, Virginia: commonwealth university.

Wong, D. k. (1991). problems of foreign students attending the university of Arkansas and recommended solutions, university of Arkansas.

Zakaria, I. \& Mukhtar, A. (2011). the status of the international student at the International Islamic University in Malaysia: Problems and treatment, research published in Islam magazine in Asia: International Islamic University in Malaysia, September 2.

Zeyada, M. A. \& Metwally, N. A. \& Noordin, S. A. \& Beet, A. s. (2006). Chapters in the meetings of Education, Riyadh: AlRashed Library. 